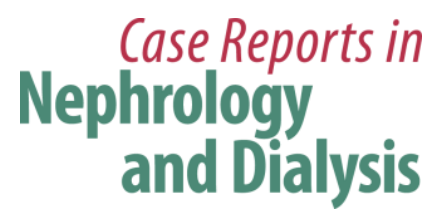

\title{
Severe, Symptomatic Hypocalcemia due to Denosumab Administration: Treatment and Clinical Course
}

\author{
Jarred Strickling Michael J. Wilkowski \\ Department of Internal Medicine, Mercer University School of Medicine - Savannah \\ Campus, Savannah, GA, USA
}

\section{Keywords}

Denosumab · Hypocalcemia · Therapy

\begin{abstract}
Denosumab is a receptor activator of nuclear factor kappa-B (RANK) ligand inhibitor used in the treatment of osteoporosis. Blockade of RANK ligand prevents osteoclastic resorption of bone, but in doing so impairs the parathyroid hormone (PTH)-driven maintenance of serum calcium. A subsequent elevation of PTH remains active at sites other than bone, potentially lowering serum phosphate by inhibiting proximal tubular reabsorption. We present 2 patients who developed severe, symptomatic hypocalcemia after administration of denosumab. These patients provide an opportunity to describe the clinical course and treatment, including the need to consider a continuous calcium infusion, of severe, symptomatic hypocalcemia caused by denosumab.

(C) 2019 The Author(s)

Published by S. Karger AG, Basel
\end{abstract}




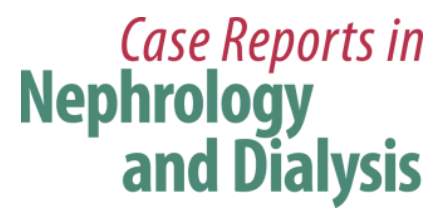

Case Rep Nephrol Dial 2019;9:33-41

DOI: $10.1159 / 000499824$

(c) 2019 The Author(s). Published by S. Karger AG, Basel www.karger.com/cnd

Strickling and Wilkowski: Severe, Symptomatic Hypocalcemia due to Denosumab Administration: Treatment and Clinical Course

\section{Introduction}

The homeostasis of calcium and phosphate is maintained by multiple hormones that act on the kidneys and bone [1]. Parathyroid hormone (PTH) exerts its effects on these organs to prevent hypocalcemia and hyperphosphatemia. Specifically, in the proximal tubules of the kidney, PTH prevents the reabsorption of phosphorus and enhances the production of 1,25dihydroxy vitamin D production [2,3], while in the distal tubules it acts to decrease calcium excretion [4]. PTH also stimulates an increase in receptor activator of nuclear factor kappa-B (RANK) ligand molecules on osteoblasts, which subsequently bind RANK to both induce differentiation of hematopoietic precursors into osteoclasts and enhance survival of mature osteoclasts, thereby increasing efflux of calcium and phosphorous from bone [5, 6]. The associated increase in blood calcium exerts negative feedback on PTH production, maintaining homeostasis.

A RANK ligand inhibitor reduces the number of active osteoclasts, reduces bone turnover and increases bone mass. The biologic agent denosumab, a monoclonal antibody that inhibits RANK ligand, is an approved agent for the treatment of osteoporosis [6]. However, bone osteoclasts' resistance to PTH created through RANK ligand blockade can cause hypocalcemia [7, 8]. This leads to elevated PTH that continues to exert its effects on renal tubules, potentially lowering serum phosphorous. We present 2 patients with severe, symptomatic hypocalcemia and dramatic elevations of PTH following denosumab treatment for osteoporosis.

\section{Case Report}

Patient 1 is an 80-year-old woman with stage 3B chronic kidney disease (CKD) who received an inadvertent dose of denosumab 1 month after her regularly scheduled dose. Eighteen days following the second dose, the patient presented to the emergency department with severe weakness that prevented her from getting out of bed. She denied seizures, syncope, chest pain, or palpitations. Neurological exam revealed $4 / 5$ strength in all extremities. Chvostek sign was absent. Chemistries revealed a serum total calcium of $4.2 \mathrm{mg} / \mathrm{dL}$, magnesium $1.2 \mathrm{mg} / \mathrm{dL}$, phosphorous $2.4 \mathrm{mg} / \mathrm{dL}$, ionized calcium $0.56 \mathrm{mmol} / \mathrm{L}$ (normal 1.11-1.3 mmol/L), 25-hydroxy vitamin D $11.0 \mathrm{ng} / \mathrm{mL}$ (normal 30-100 ng/mL), and intact PTH was $>3,639 \mathrm{pg} / \mathrm{mL}$ (normal $14-60 \mathrm{pg} / \mathrm{mL}$ ). Her eGFR on admission was $31 \mathrm{~mL} / \mathrm{min} / 1.72 \mathrm{~m}^{2}$, and her serum creatinine was $1.9 \mathrm{mg} / \mathrm{dL}$ (baseline between 1.5 and $2 \mathrm{mg} / \mathrm{dL}$ ). Two months prior to admission she had a serum calcium of $9.2 \mathrm{mg} / \mathrm{dL}$. ECG revealed prolonged QT interval of $479 \mathrm{~ms}$ and prominent T waves. These two changes caused the automated interpretation of the ECG to indicate a heart rate $133 / \mathrm{min}$, while her clinicians interpreted the heart rate to be 75 (Fig. 1).

Patient 2 is a 66-year-old woman with a history of Crohn's disease and an ileostomy. She presented to the emergency department with profound, debilitating weakness 22 days following her regularly scheduled dose of denosumab. She had received biannual treatments for 5 years at this point. Neurological exam revealed 5-/5 strength in all extremities. She exhibited mild psychomotor slowing. Chvostek sign was absent. Serum chemistries demonstrated a serum total calcium of $4.5 \mathrm{mg} / \mathrm{dL}$, magnesium $1.6 \mathrm{mg} / \mathrm{dL}$, phosphorous of $<1.0 \mathrm{mg} / \mathrm{dL}$, ionized calcium $0.89 \mathrm{mmol} / \mathrm{L}$ and intact PTH 2,356 pg/mL. 25-hydroxy vitamin D was $4 \mathrm{ng} / \mathrm{mL}$. The 


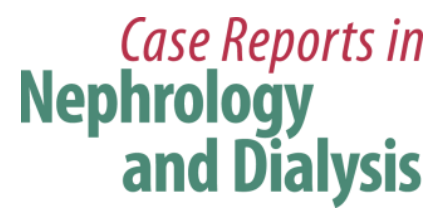

\begin{tabular}{l|l} 
Case Rep Nephrol Dial 2019;9:33-41 \\
\hline DOI: 10.1159/000499824 & $\begin{array}{l}\text { (c) } 2019 \text { The Author(s). Published by S. Karger AG, Basel } \\
\text { www.karger.com/cnd }\end{array}$
\end{tabular}

Strickling and Wilkowski: Severe, Symptomatic Hypocalcemia due to Denosumab Administration: Treatment and Clinical Course

last prior vitamin D measurement in our records was 2 years prior and measured $<4.0 \mathrm{ng} / \mathrm{mL}$. This measurement was drawn 2 weeks after a dose of denosumab was administered, and the importance of supplementation was reinforced to the patient at that time. This patient had no evidence of CKD with an eGFR of $101 \mathrm{~mL} / \mathrm{min} / 1.72 \mathrm{~m}^{2}$ and a serum creatinine of $0.7 \mathrm{mg} / \mathrm{dL}$. It should be noted that patient 2 had a history of mild, asymptomatic hypocalcemia (with values ranging from 6.0 to $10.4 \mathrm{mg} / \mathrm{dL}$ ) in the year prior to admission with an intact PTH ranging between 300 and $500 \mathrm{pg} / \mathrm{mL}$ and mildly low serum phosphorous levels. Vitamin D deficiency limiting intestinal phosphorous absorption and denosumab-induced elevated PTH levels causing phosphaturia would account for hypophosphatemia. Patients with vitamin D deficiency in the absence of denosumab treatment typically have mildly elevated PTH levels, though generally no higher than $110 \mathrm{pg} / \mathrm{mL}$ [9]. The laboratory findings upon admission of both patients are presented in Table 1 .

Patient 1 received two doses of $2 \mathrm{~g}$ of calcium gluconate IV followed by $320 \mathrm{mg}$ of calcium gluconate per hour ( $4 \mathrm{~g}$ calcium gluconate in $500 \mathrm{~mL} \mathrm{D5W}$ at $40 \mathrm{~mL}$ per hour) as a constant infusion. This infusion maintained serum calcium levels between 5.1 and $8.0 \mathrm{mg} / \mathrm{dL}$ and resolved the weakness and normalized QTc. Patient 2 received $2 \mathrm{~g}$ calcium gluconate IV every $6 \mathrm{~h}$. Serum calcium checks ranged between 4.9 and $6.4 \mathrm{mg} / \mathrm{dL}$.

Both patients received the same oral supplementation with $1 \mathrm{~g}$ of calcium carbonate four times daily, ergocalciferol 5,000 units daily, and calcitriol $1 \mu \mathrm{g}$ twice per day. Both patients received 1-2 g magnesium sulfate IV for hypomagnesemia when indicated. Patient 2 also received oral phosphate supplementation. After stabilization, patients 1 and 2 were discharged on hospital days 4 and 8 , respectively. They were discharged on a regimen of calcitriol capsules, calcium carbonate tablets, magnesium oxide supplements, and cholecalciferol capsules. In patient 1 , we saw an increase in vitamin D level from $11.0 \mathrm{ng} / \mathrm{mL}$ on admission to 16.0 $\mathrm{ng} / \mathrm{mL} 2$ weeks later, and $36.0 \mathrm{ng} / \mathrm{mL}$ at a 3-month follow-up. Her phosphorous was 3.4 $\mathrm{mg} / \mathrm{dL}$ at 3-month follow-up. She was noted to have continued PTH resistance 3 weeks following discharge (intact PTH remained $>3,639 \mathrm{pg} / \mathrm{mL}$ and serum calcium was $6.2 \mathrm{mg} / \mathrm{dL}$ ), but after 3 months PTH and total calcium normalized. Patient 2 saw an increase in vitamin D from $4.0 \mathrm{ng} / \mathrm{mL}$ on admission to $15 \mathrm{ng} / \mathrm{mL}$ at a 3-week follow-up, and an increase in phosphorous from $<1.0 \mathrm{mg} / \mathrm{dL}$ to $3.1 \mathrm{mg} / \mathrm{dL}$ within a week of treatment. Her hypocalcemia resolved 3 weeks following discharge, and PTH level was not remeasured. Follow-up laboratory values for both patient 1 and 2 are found in Table 2 .

\section{Discussion}

Hypocalcemia is not a rare adverse event following the administration of denosumab. A study involving 2,841 patients receiving treatment with the drug found that $9.6 \%$ developed at least mild hypocalcemia, while $3.1 \%$ developed severe hypocalcemia, defined as serum calcium of $<7.0 \mathrm{mg} / \mathrm{dL}$ and ionized calcium $<0.9 \mathrm{mmol} / \mathrm{L}$ [10]. Patients with a low baseline GFR are at significantly increased risk for developing hypocalcemia while on denosumab, and the degree of decrease in GFR correlates with the degree of hypocalcemic severity [11]. The FREEDOM trial demonstrated denosumab treatment to be effective in reducing fracture risk and did not find increased risk of adverse events in patients with GFR $\geq 30$. There were too few patients to draw conclusions on increased risk of patients with GFR $<30$ [12]. Of our 2 patients, 


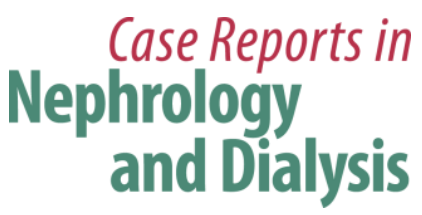

\begin{tabular}{l|l} 
Case Rep Nephrol Dial 2019;9:33-41 \\
\hline DOI: 10.1159/000499824 & $\begin{array}{l}\text { (c) 2019 The Author(s). Published by S. Karger AG, Basel } \\
\text { www.karger.com/cnd }\end{array}$
\end{tabular}

patient 1 has a diagnosis of stage 3B CKD with a GFR on admission of $31 \mathrm{~mL} / \mathrm{min}$. Her ionized calcium was $0.33 \mathrm{mmol} / \mathrm{L}$ lower than that of patient 2, and her intact PTH was higher. While this is likely due to patient 1 receiving an extra dose of denosumab, her decreased kidney function may be a contributing factor to her degree of hypocalcemia and increase in PTH.

It is well known that a secondary hyperparathyroidism develops in patients with CKD [13, 14]. The cause is multifactorial: low serum calcium arising from decreased 1,25-dihydroxy vitamin $\mathrm{D}$ production, elevated serum phosphorous decreasing the ionized calcium level and directly stimulating PTH production, and elevated fibroblast growth factor-23 (FGF-23) level possibly increasing PTH secretion [15]. Normally, PTH raises serum calcium by increasing calcium reabsorption in the distal nephron and liberating calcium by stimulating osteoclastic resorption of bone [1, 4]. Our 2 patients essentially lost this osteoclastic activation arm of PTHinduced calcium regulation, and this manifested as severe, symptomatic hypocalcemia even with normal kidney reabsorption. The distal tubular resorptive action of PTH was insufficient to keep ionized calcium in the asymptomatic range.

In addition to calcium homeostasis, PTH regulates serum phosphorous. PTH is a phosphaturic factor that decreases reabsorption in the proximal tubule and increases urinary excretion [2]. Renal phosphorous excretion offsets the rising serum levels caused by PTH-driven bone resorption [16]. Patients with primary hyperparathyroidism exhibit mild reductions in serum phosphorous levels [17]. However, denosumab induces a PTH resistance specific to the bone, and the increasing PTH levels cause increased phosphorous excretion in the absence of osteoclastic liberation of bone phosphorous, overall leading to hypophosphatemia. Hypophosphatemia (defined as less than the lower limit of normal) has been shown to occur in $2.1 \%$ of patients treated with denosumab [9]. This is evident in patient 2. On admission, her serum phosphorous was $<1.0 \mathrm{mg} / \mathrm{dL}$, no doubt exacerbating her weakness. Her intact PTH was 2,356 $\mathrm{pg} / \mathrm{mL}$, presumably enough to cause phosphaturia. In addition, her vitamin D deficiency, presumably due to Crohn's disease and malabsorption, contributed to the hypophosphatemia. In contrast to patient 2 , patient 1 presented with even higher PTH levels yet maintained a normal serum phosphorous of $2.4 \mathrm{mg} / \mathrm{dL}$. Stage 3B CKD is the likely explanation [18]. While CKD may predispose patients receiving denosumab to hypocalcemia [10,19], it seems reasonable that it has a protective effect against hypophosphatemia, as is evidenced by our case as well as others [20,21].

The calcium lowering effect of denosumab requires that patients receiving treatments be supplemented with calcium and vitamin $\mathrm{D}$, as does the standard treatment of osteoporosis requires calcium and vitamin D supplementation. Patients receiving denosumab monotherapy show at least a minor decrease in serum calcium, as would be expected, but patients receiving concurrent calcium and vitamin D supplementation show no such decrease [22]. The FDA recommends $1,000 \mathrm{mg}$ calcium and $400 \mathrm{IU}$ of vitamin D daily with denosumab treatments, and any preexisting hypocalcemia to be corrected prior to initiation of therapy [23]. Our patients were prescribed adequate supplementation. However, patient 2 was noted to exhibit vitamin D deficiency during treatment that, although supplemented, never normalized. No strict rule exists on vitamin D status at treatment initiation, only that supplementation is begun. Patient 2 provides evidence that correction of vitamin D deficiency should be addressed prior to denosumab administration. 


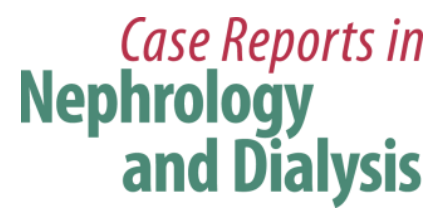

\begin{tabular}{l|l} 
Case Rep Nephrol Dial 2019;9:33-41 \\
\hline DOI: 10.1159/000499824 & $\begin{array}{l}\text { (c) } 2019 \text { The Author(s). Published by S. Karger AG, Basel } \\
\text { www.karger.com/cnd }\end{array}$
\end{tabular}

Strickling and Wilkowski: Severe, Symptomatic Hypocalcemia due to Denosumab Administration: Treatment and Clinical Course

Finally, we will discuss the treatment of severe hypocalcemia. For patients with symptoms or an ionized calcium of $<0.7 \mathrm{mmol} / \mathrm{L}$, one author recommends $1-2 \mathrm{~g}$ of calcium gluconate over $10 \mathrm{~min}$ followed by an infusion of $0.3-2 \mathrm{mg} / \mathrm{kg} / \mathrm{h}$ for several hours [24]. A more recent study of 8 patients with moderate to severe hypocalcemia (ionized calcium $<1.0$ $\mathrm{mmol} / \mathrm{L}$ ) admitted to a trauma intensive care unit found that treatment with 2-4 g (based on body weight) of IV calcium gluconate infused at $1 \mathrm{~g} / \mathrm{h}$ was only effective in normalizing serum ionized calcium in 3 of the 8 patients, and 1 developed mild hypercalcemia. They concluded that the individual response to calcium therapy is highly variable [25]. The current texts cite Cooper who states that acute hypocalcemic crisis be treated with an initial bolus of one or two $10 \mathrm{~mL}$ ampules of $10 \%$ calcium gluconate diluted in $50-100 \mathrm{~mL}$ of $5 \%$ dextrose and infused over $10 \mathrm{~min}$. Subsequently, ten $10 \mathrm{~mL}$ ampules of $10 \%$ calcium gluconate diluted in $1 \mathrm{~L}$ of $5 \%$ dextrose may be given at an initial infusion rate of $50 \mathrm{~mL} / \mathrm{h}$, attempting to maintain serum calcium at the lower end of the normal range [26]. Our review of the literature for accepted guidelines yielded an online publication by the British-based Society for Endocrinology [27].

Our approaches follow the general ideas outlined above and allow us to compare bolus treatments with a constant infusion. Patient 1 was given initial boluses with two doses of $2 \mathrm{~g}$ IV calcium gluconate within an hour of each other followed by administration of $320 \mathrm{mg}$ of calcium gluconate per hour ( $4 \mathrm{~g}$ calcium gluconate in $500 \mathrm{~mL}$ D W at $40 \mathrm{~mL}$ per hour) which maintained her serum calcium between 5.1 and $8 \mathrm{mg} / \mathrm{dL}$ and resolved her weakness. Patient 2 received a similar initial bolus of two doses of $2 \mathrm{~g}$ IV calcium gluconate within an hour followed by $2 \mathrm{~g}$ calcium gluconate IV Q $6 \mathrm{~h}$ which maintained her calcium between 4.9 and 6.3 $\mathrm{mg} / \mathrm{dL}$. In comparison, the constant infusion given to patient 1 maintained higher serum calcium levels, improved weakness, and resulted in earlier discharge relative to patient 2 . Of note, the serum calcium of patient 1 did reach a level of $8.0 \mathrm{mg} / \mathrm{dL}$, indicating a need to be cognizant of the potential for iatrogenic hypercalcemia on a constant calcium infusion. On admission, the patients began oral supplementation with $1 \mathrm{~g}$ of calcium carbonate four times daily, ergocalciferol 5,000 units daily, and calcitriol $1 \mu \mathrm{g}$ twice per day. Patient 2 continued oral calcium carbonate, and both patients continued magnesium and vitamin D supplementation following discharge. At a 3-month follow up, patient 1's serum calcium finally reached normal. At a 3week follow up, patient 2's serum calcium was normal. The difference in time to complete resolution was attributed to patient 1 receiving an inadvertent dose of denosumab which has a half-life of 25-30 days [28].

\section{Statement of Ethics}

The patients in this study provided written informed consent for use of their clinical information for inclusion in a medical publication.

\section{Disclosure Statement}

The authors have no conflicts of interest to declare. 
Funding Sources

No funding was used to support this effort.

\section{Author Contributions}

Both authors contributed equally to the literature review, text of the manuscript, and patients' follow-up care. Dr. Wilkowski was responsible for the original diagnosis and treatment.

\section{References}

1 Quarles LD. Endocrine functions of bone in mineral metabolism regulation. J Clin Invest. 2008 Dec;118(12):3820-8.

2 Harrison HE, Harrison HC. The renal excretion of inorganic phosphate in relation to the action of vitamin d and parathyroid hormone. J Clin Invest. 1941 Jan;20(1):47-55.

3 Lee JJ, Plain A, Beggs MR, Dimke H, Alexander RT. Effects of phospho- and calciotropic hormones on electrolyte transport in the proximal tubule. F1000 Res. 2017 Oct;6:1797.

4 Greger R, Lang F, Oberleithner H. Distal site of calcium reabsorption in the rat nephron. Pflugers Arch. 1978 May;374(2):153-7.

5 Ma YL, Cain RL, Halladay DL, Yang X, Zeng Q, Miles RR, et al. Catabolic effects of continuous human PTH (138 ) in vivo is associated with sustained stimulation of RANKL and inhibition of osteoprotegerin and geneassociated bone formation. Endocrinology. 2001 Sep;142(9):4047-54.

6 Lacey DL, Boyle WJ, Simonet WS, Kostenuik PJ, Dougall WC, Sullivan JK, et al. Bench to bedside: elucidation of the OPG-RANK-RANKL pathway and the development of denosumab. Nat Rev Drug Discov. 2012 May;11(5):401-19.

7 Wada T, Nakashima T, Hiroshi N, Penninger JM. RANKL-RANK signaling in osteoclastogenesis and bone disease. Trends Mol Med. 2006 Jan;12(1):17-25.

8 Rosner MH. Hypocalcemia in a Patient with Cancer. Clin J Am Soc Nephrol. 2017 Apr;12(4):696-9.

9 Sadat-Ali M, Al-Omran AS, Al-Turki HA. Parathyroid Glands response to Low Vitamin D levels in Healthy Adults: A Cross-Sectional Study. Ulster Med J. 2015 Jan;84(1):26-9.

10 Lipton A, Fizazi K, Stopeck AT, Henry DH, Brown JE, Yardley DA, et al. Superiority of denosumab to zoledronic acid for prevention of skeletal-related events. Eur J Cancer. 2012;48:3082-92.

11 Ikesue H, Tsuji T, Hata K, Watanabe H, Mishima K, Uchida M, et al. Time Course of Calcium Concentrations and Risk Factors for Hypocalcemia in Patients Receiving Denosumab for the Treatment of Bone Metastases From Cancer. Ann Pharmacother. 2014 Sep;48(9):1159-65.

12 Jamal SA, Ljunggren O, Stehman-Breen C, Cummings SR, McClung MR, Goemaere S, et al. Effects of denosumab on fracture and bone mineral density by level of kidney function. J Bone Miner Res. 2011 Aug;26(8):1829-35.

13 Wei-Hao W, Li-Wei C, Chin-Chan L, Chiao-Yin S, Yu-Chiau S, Heng-Rong H, et al. Association between Parathyroid Hormone, 25(OH) Vitamin D, and Chronic Kidney Disease: A Population-Based Study. Biomed Res Int 2017;2017

14 Padagas J, Colloton M, Shalhoub V, Kostenuik P, Morony S, Munyakazi L, et al. The receptor activator of nuclear factor-kappaB ligand inhibitor osteoprotegerin is a bone-protective agent in a rat model of chronic renal insufficiency and hyperparathyroidism. Calcif Tissue Int. 2006 Jan;78(1):35-44.

15 Evenepoel P, Bover J, Ureña Torres P. Parathyroid hormone metabolism and signaling in health and chronic kidney disease. Kidney Int. 2016 Dec;90(6):1184-90.

16 Shiraki M, Gee MV, Baum BJ, Roth GS. Parathyroid hormone stimulates phosphate efflux through an apparently adenosine $3^{\prime}, 5^{\prime}$-monophosphate-independent process in rat parotid cell aggregates. Endocrinology. 1986 May;118(5):2009-15.

17 Wang Q, Li X, Chen H, Yu H, Li L, Yin J, et al. The chloride/phosphate ratio combined with alkaline phosphatase as a valuable predictive marker for primary hyperparathyroidism in Chinese individuals. Sci Rep. 2017 Jul;7(1):4868. 


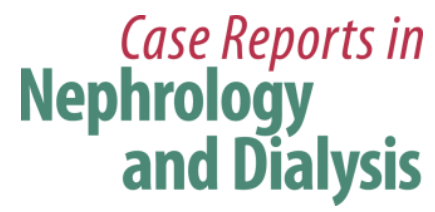

\begin{tabular}{l|l}
\hline Case Rep Nephrol Dial 2019;9:33-41 \\
\hline DOI: 10.1159/000499824 & $\begin{array}{l}\text { (c) } 2019 \text { The Author(s). Published by S. Karger AG, Basel } \\
\text { www.karger.com/cnd }\end{array}$
\end{tabular}

Strickling and Wilkowski: Severe, Symptomatic Hypocalcemia due to Denosumab Administration: Treatment and Clinical Course

18 Toussaint ND, Holt SG. Is serum phosphate a useful target in patients with chronic kidney disease and what is the role for dietary phosphate restriction? Nephrology (Carlton). 2017 Mar;22 Suppl 2:36-41.

19 Dave V, Chiang CY, Booth J, Mount PF. Hypocalcemia post denosumab in patients with chronic kidney disease stage 4-5. Am J Nephrol. 2015;41(2):129-37.

20 Oiwa H, Mokuda S. Severe hypocalcemia and prolonged QT interval due to denosumab in an elderly woman with rheumatoid arthritis and chronic kidney disease. Eur J Rheumatol. 2016 Sep;3(3):144-5.

21 Killen JP, Yong K, Luxton G, Endre Z. Life-threatening hypocalcaemia associated with denosumab in advanced chronic kidney disease. Intern Med J. 2016 Jun;46(6):746-7.

22 Nakamura Y, Suzuki T, Kamimura M, Ikegami S, Murakami K, Uchiyama S, et al. Two-year clinical outcome of denosumab treatment alone and in combination with teriparatide in Japanese treatment-naive postmenopausal osteoporotic women. Bone Res. 2017 Jun;5:16055.

23 U.S. Food and Drug Administration/Center for Drug Evaluation and Research: Prolia (denosumab). 2011.

24 Zaloga GP. Hypocalcemic crisis. Crit Care Clin. 1991 Jan;7(1):191-200.

25 Dickerson RN, Morgan LG, Cauthen AD, Alexander KH, Croce MA, Minard G, et al. Treatment of acute hypocalcemia in critically ill multiple-trauma patients. JPEN J Parenter Enteral Nutr. 2005 NovDec;29(6):436-41.

26 Cooper MS, Gittoes NJ. Diagnosis and management of hypocalcaemia. BMJ. 2008 Jun;336(7656):1298-302.

27 Turner J, Gittoes N, Selby P; Society for Endocrinology Clinical Committee. Society for Endocrinology Endocrine Emergency Guidance: Emergency management of acute hypocalcemia in adult patients. Endocr Connect. 2016 Sep;5(5):G7-G8.

28 Gibiansky L, Sutjandra L, Doshi S, Zheng J, Sohn W, Peterson MC, et al. Population pharmacokinetic analysis of denosumab in patients with bone metastases from solid tumours. Clin Pharmacokinet. 2012 Apr;51(4):247-60. 


\section{Case Reports in Nephrology and Dialysis}

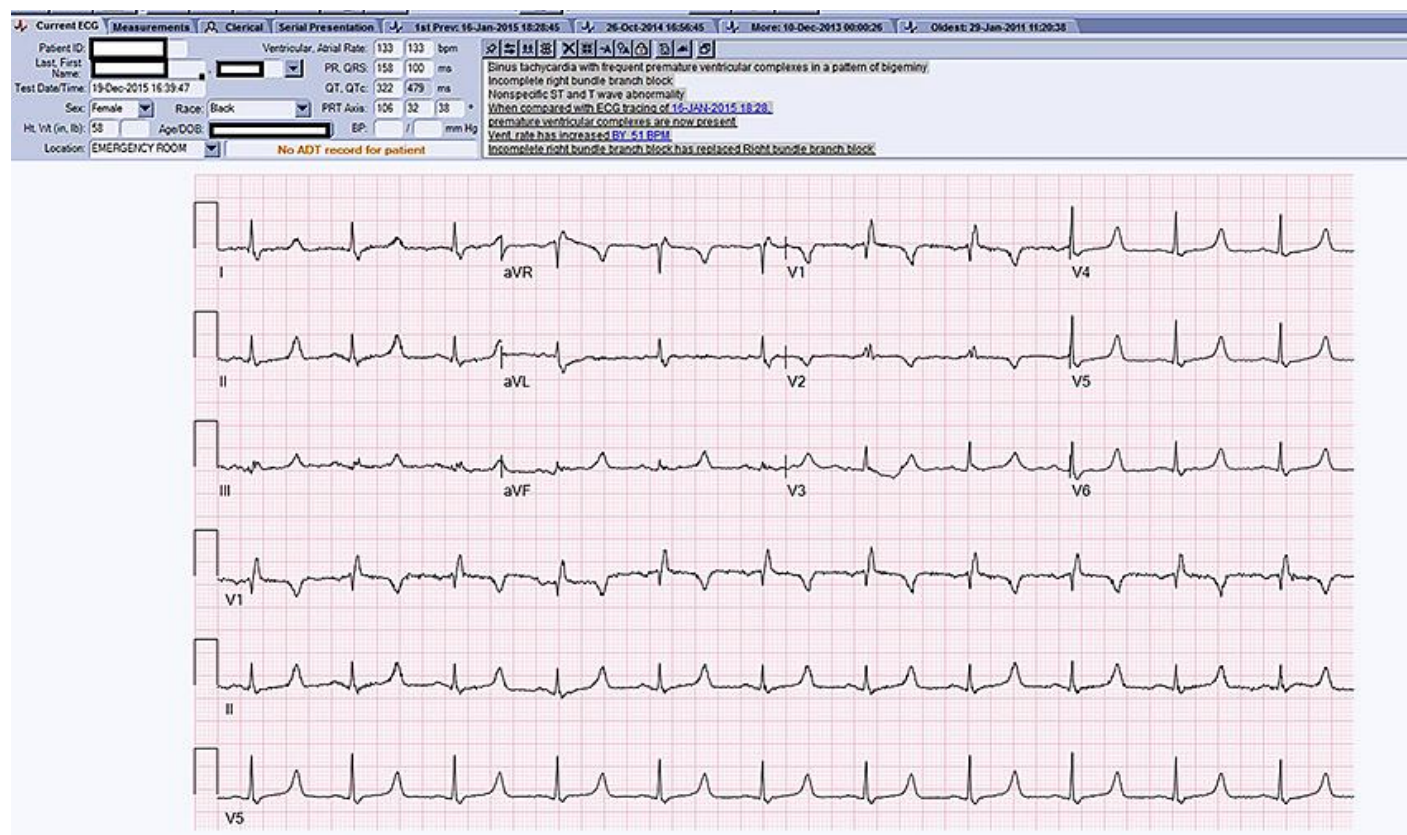

Fig. 1. Patient 1 ECG on admission is incorrectly interpreted by the computer as tachycardia with a rate of $133 /$ min with premature ventricular contractions due to the prolonged QT interval and prominent $\mathrm{T}$ waves. The correct interpretation is sinus rhythm with a rate of $65 / \mathrm{min}$ and no premature ventricular contractions. The right bundle branch block is unchanged from her baseline.

Table 1. Patient 1 and 2 laboratory values upon admission

\begin{tabular}{lrrl}
\hline \multirow{2}{*}{$\begin{array}{l}\text { Laboratory values } \\
\text { (normal) }\end{array}$} & \multicolumn{3}{l}{ Admissions } \\
\cline { 2 - 4 } & patient 1 & patient 2 & units \\
\hline Serum total calcium & 4.2 & 4.5 & $\mathrm{mg} / \mathrm{dL}$ \\
Ionized Ca ${ }^{2+}$ & 0.56 & 0.89 & $\mathrm{mmol} / \mathrm{L}$ \\
(1.1-1.4 mmol/L) & & & \\
Serum Mg2+ & 1.2 & 1.8 & $\mathrm{mg} / \mathrm{dL}$ \\
Serum phosphate & 2.4 & $<1.0$ & $\mathrm{mg} / \mathrm{dL}$ \\
Intact PTH (14-60 pg/mL) & $>3,639$ & 2,356 & $\mathrm{pg} / \mathrm{mL}$ \\
Serum creatinine & 1.9 & 0.7 & $\mathrm{mg} / \mathrm{dL}$ \\
GFR & 31 & 101 & $\mathrm{~mL} / \mathrm{min} / 1.72 \mathrm{~m}^{2}$ \\
Vitamin D (30-80 ng/mL) & 11 & 4 & $\mathrm{ng} / \mathrm{mL}$ \\
\hline
\end{tabular}




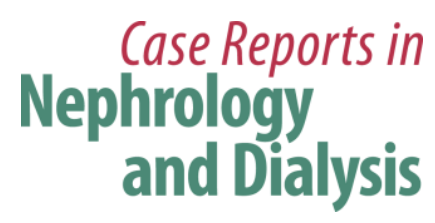

Case Rep Nephrol Dial 2019:9·33-41

DOI: $10.1159 / 000499824$

(c)

(C) 2019 The Author(s). Published by S. Karger AG, Basel www.karger.com/cnd

Strickling and Wilkowski: Severe, Symptomatic Hypocalcemia due to Denosumab

Administration: Treatment and Clinical Course

Table 2. Laboratory values at follow-up appointments

Laboratory values Follow-ups

(normal)

$1-2$ weeks

3 weeks

patient 1 patient 2 patient 1 patient 2

\section{3 months}

patient 1 patient 2

\section{6-17 months}

patient 1 patient 2 patient 2 patient 1

\section{0-33 months}

units

\begin{tabular}{|c|c|c|c|c|c|c|c|c|c|c|c|}
\hline $\begin{array}{l}\text { Serum total } \\
\text { calcium }\end{array}$ & 6.4 & 5.9 & 6.2 & 9.4 & 9.5 & NA & 9.5 & 9.2 & 8.9 & 9.0 & $\mathrm{mg} / \mathrm{dL}$ \\
\hline $\begin{array}{l}\text { Serum phos- } \\
\text { phate }\end{array}$ & 3.1 & 1.6 & NA & 2.2 & 3.4 & NA & 3.4 & 3.2 & 3.2 & 3.7 & $\mathrm{mg} / \mathrm{dL}$ \\
\hline $\begin{array}{l}\text { Intact PTH } \\
(14-60 \mathrm{mg} / \mathrm{mL})\end{array}$ & NA & NA & $>3,639$ & NA & 315 & NA & 96 & NA & NA & NA & $\mathrm{pg} / \mathrm{mL}$ \\
\hline $\begin{array}{l}\text { 25-vitamin D } \\
(30-80 \mathrm{ng} / \mathrm{mL})\end{array}$ & NA & 16 & NA & 15 & 36 & NA & NA & NA & NA & NA & $\mathrm{mg} / \mathrm{dL}$ \\
\hline
\end{tabular}

\section{Serum total}

Note the continued PTH resistance and ongoing hypocalcemia in patient 1 . PTH levels were not trended in patient 2 as calcium and phosphate levels normalized by second follow-up. NA, not available. 